\title{
Ecological investigations on Hydrophilidae and Helophoridae (Coleoptera) specimens gathered from several water bodies of Western Turkey
}

\author{
Ayçin Akünal ${ }^{1, *}$ and Ebru Gül Aslan ${ }^{2}$ \\ ${ }^{1}$ Department of Emergency and Disaster Management, Beysehir Ali Akkanat School of Applied Sciences, Selçuk University, \\ 42700 Beysehir/Konya, Turkey \\ ${ }^{2}$ Department of Biology, Faculty of Arts and Sciences, Süleyman Demirel University, 32260 Isparta, Turkey
}

\begin{abstract}
The aim of this study is to present environmental variables which were effective on habitat preferences of Hydrophilidae and Helophoridae species found in western region of Turkey. The surveys were conducted in İzmir, Manisa and Aydın provinces and specimens were collected regularly during the years 2013 and 2014. Totally, 30 species classified in 8 genera of the two families were recorded. Physicochemical parameters including temperature, dissolved oxygen, $\mathrm{pH}$, electrical conductivity and salinity were measured from 99 different aquatic sites. The relationships between the species and the effect (s) of the mentioned parameters on the presence or absence of the beetles were evaluated by various statistical tests. According to the results; electrical conductivity, salinity and temperature are the main water parameters associated with aquatic beetle distribution. Pearson's correlation analysis coefficient between the salinity and electrical conductivity parameters was calculated as 0.965 which is statistically significant $(p<0.01)$. The relationships between environmental variables and the determined species were also evaluated with canonical correspondence analysis (CCA), and the distributions of species according to these variables were presented by using a CCA plot.
\end{abstract}

Keywords: Hydrophilidae / Helophoridae / ecology / CCA / Turkey

Résumé - Investigations écologiques sur des échantillons d'Hydrophilidés et d'Hélophoridés (Coleoptera) collectés dans plusieurs cours d'eau de Turquie occidentale. La présente étude visait à rechercher des variables environnementales qui étaient déterminantes sur les préférences d'habitat des espèces d'Hydrophilidés et d'Hélophoridés présentes en Turquie occidentale. Des échantillonnages ont été menés dans les provinces d'İzmir, Manisa et Aydın en Turquie et des spécimens ont été recueillis régulièrement en 2013 et 2014. Au total, 30 espèces de 8 genres des deux familles ont été récoltées. Les paramètres physicochimiques incluant la température, l'oxygène dissous, le $\mathrm{pH}$, la conductivité électrique et la salinité ont été mesurés dans 99 sites aquatiques différents. Les relations entre espèces et l'effet(s) des paramètres mentionnés sur la présence ou l'absence des coléoptères ont été évaluées par divers tests statistiques. Selon les résultats; la conductivité électrique, la salinité et la température sont les principaux paramètres associés à la distribution des coléoptères aquatiques. Le coefficient de corrélation de Pearson entre la salinité et les paramètres de conductivité électrique est de 0.965 , statistiquement significatif $(p<0.01)$. Les relations entre les variables environnementales et les espèces déterminées ont également été évaluées par analyse canonique de correspondance (CCA), et les distributions des espèces selon ces variables ont été présentées en utilisant un diagramme CCA.

Mots-clés : Hydrophilidae / Helophoridae / écologie / CCA / Turquie 


\section{Introduction}

Aquatic insects comprise an important part of the aquatic ecosystems, and essential components of biodiversity. They play a very significant role in nutrients' recycling; form an important portion of natural food web in aquatic ecosystems (Ramnik Kour and Sharma, 2011), and are the organism affected most by surface water pollution. They are diverse, vulnerable, and they react to both natural and manmade changes in the environment directly (Arimoro and Ikomi, 2009). As an important component of aquatic biodiversity, the invertebrate fauna constitutes a fundamental part of these ecosystems and has become a useful element for the environmental variables that influence their composition and richness patterns determining their diversity. Species-level identification for all aquatic invertebrates is generally problematic because of the aerial stage of most adults. Only some Coleoptera and Hemiptera adults are strictly aquatics (Guareschi et al., 2012). Coleoptera is a diverse order with over 5000 aquatic species, its physiological and behavioral adaptation has an advantage over other macro-zoo-benthos of fresh water habitats (Ramnik Kour and Sharma, 2011; Smith and Golladay, 2011), and is also the richest insect order in inland saline waters (Pallarés et al., 2012).

Water temperature, $\mathrm{pH}$, dissolved oxygen, turbidity, flow rate and density, substratum characteristics, heavy metal ratio, salinity, electrical conductivity, etc., are among the effective ecological variables responsible for habitat preferences of aquatic insects (Heino, 2009). Because they are effected directly by any change in water quality, they are used as bioindicators, or for biomonitoring activities. The concept of biological indicators and biological monitoring using aquatic insects is based on their diversity, abundance and distribution in relation to the physical and chemical conditions of the habitats (Wahizatul et al., 2011).

Hydrophilidae and Helophoridae represent two important aquatic groups of Hydrophiloidea, and are not yet studied enough in Turkey. Faunistic studies have been done mainly in the Eastern, Northern, Central Anatolia and Inner Western parts of Turkey lacking any information about the ecology and habitat associations of the species (Kiyak et al., 2006; Ertorun and Tanatmıs, 2009; Incekara et al., 2009, 2010; Mart, 2009; Mart et al., 2010, 2014; Polat et al., 2010; Topkara and Balık, 2010; Tasar et al., 2012). Studies based on how physicochemical parameters of water affect species' distribution, or which environmental variables have primary impact on habitat preferences of Hydrophilidae and Helophoridae species are almost absent.

İzmir, Manisa and Aydın provinces are located in the western part of Turkey and despite the fact that they have numerous water sources with different topographic structures, there are almost no comprehensive faunistic surveys conducted on these two families there. Therefore the aims of this study are; to measure some environmental variables (including the water temperature, dissolved oxygen, $\mathrm{pH}$, electrical conductivity, and salinity parameters) that are thought to be effective in sampled habitats which were chosen or not chosen by the species, and to estimate the effects of these parameters on habitat preferences of these beetles, as well as relationship between the environmental factors and species' distribution according to the data obtained.

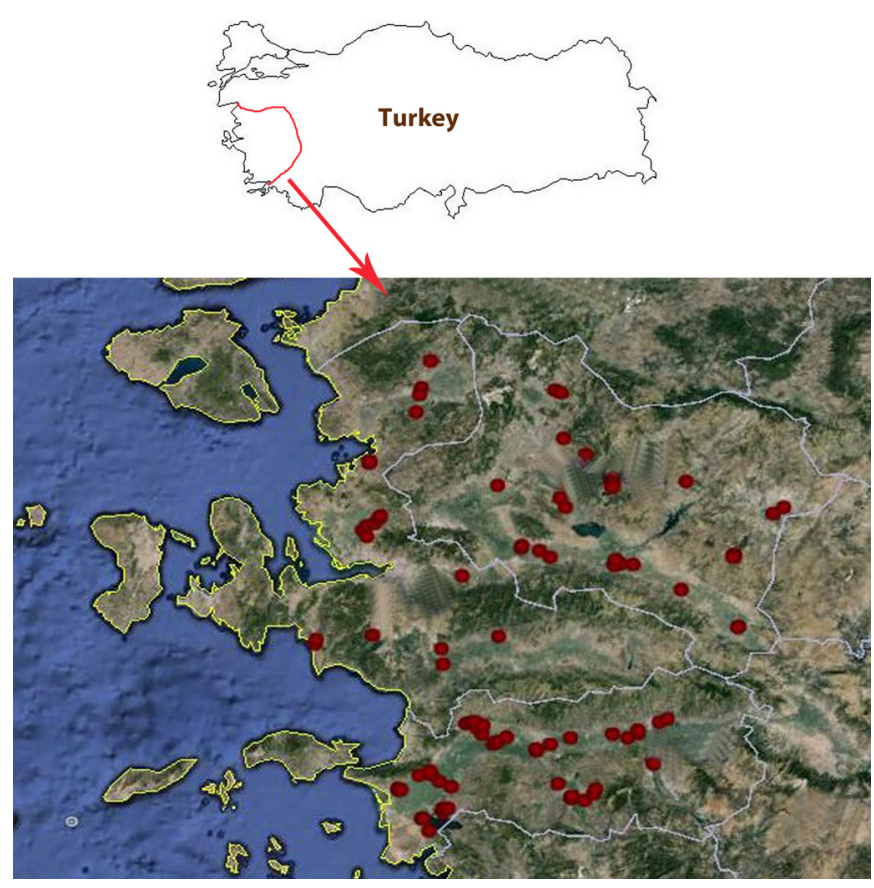

Fig. 1. Map of the study area showing distribution of the 99 sampling sites.

\section{Materials and methods}

\subsection{Study area and sampling method}

This study is based on Hydrophilidae and Helophoridae specimens gathered from February to November in 2013-2014 from İzmir, Manisa, and Aydın provinces (Fig. 1). All these three provinces have rich composition in terms of diverse aquatic habitats. Investigations were carried out in 99 different sampling sites (20 sites from İzmir, 35 sites from Manisa, and 44 sites from Aydin) including the towns and their outskirts. Water samples were analyzed for various variables such as temperature $\left({ }^{\circ} \mathrm{C}\right), \mathrm{pH}$, dissolved oxygen (DO), electrical conductivity (EC) and salinity. All parameters were measured in situ by using portable multiparameter equipment (YSI Professional Plus Quatro ISE-ISE-DO-COND-T 13E100074) in order to determine the relationship between species and environmental variables.

Specimens were collected by using a sieve, ladle or net with a diameter of 1-2 mm pore, from different water bodies, from the edges of water, or under the decomposing organic matter. Samples were killed by ethyl acetate or with $70 \%$ alcohol solution and taken to the laboratory for further analysis and dissection. Diagnosis of beetles was carried out using aedeagophores and other morphological characters. All specimens are deposited at the Biology Department of Süleyman Demirel University, Isparta.

\subsection{Statistical analysis}

The first classification was performed by using MINITAB 16 on calculated descriptive statistics in order to get the arithmetic means of all parameters obtained from the 99 different sampling sites. Pearson's Correlation Analysis was 
Table 1. List of aquatic beetles (Hydrophilidae, Helophoridae) collected from Western Turkey (İzmir, Manisa and Aydın).

\begin{tabular}{|c|c|c|c|}
\hline Species & İzmir & Manisa & Aydın \\
\hline \multicolumn{4}{|l|}{ Paracymus } \\
\hline P. aeneus & + & & \\
\hline \multicolumn{4}{|l|}{ Enochrus } \\
\hline E. bicolor & + & + & + \\
\hline E. fuscipennis & & + & + \\
\hline E. halophilus & + & + & \\
\hline E. politus & + & + & \\
\hline E. quadripunctatus & + & + & \\
\hline \multicolumn{4}{|l|}{ Helochares } \\
\hline H. lividus & + & + & \\
\hline H. obscurus & + & & \\
\hline H. punctatus & + & + & \\
\hline \multicolumn{4}{|l|}{ Hydrobius } \\
\hline Hy. fuscipes & + & & + \\
\hline \multicolumn{4}{|l|}{ Hydrochara } \\
\hline Hyd. caraboides & & + & \\
\hline \multicolumn{4}{|l|}{ Laccobius } \\
\hline L. chiesai & + & + & \\
\hline L. halophilus & + & & + \\
\hline L. obscratus orchymonti & + & + & + \\
\hline L. scutellaris & + & & + \\
\hline L. simulatrix & & + & + \\
\hline L. striatulus & & + & \\
\hline L. syriacus & + & + & \\
\hline L. alternus & & & + \\
\hline L. gracilis & + & + & + \\
\hline \multicolumn{4}{|l|}{ Coelostoma } \\
\hline C. orbiculare & & + & \\
\hline \multicolumn{4}{|l|}{ Helophorus } \\
\hline Hlp. micans & & + & + \\
\hline Hlp. aquaticus & & & + \\
\hline Hlp. grandis & + & + & + \\
\hline Hlp. syriacus & & & + \\
\hline Hlp. brevipalpis & + & + & + \\
\hline Hlp. flavipes & & & + \\
\hline Hlp. hilaris & & & + \\
\hline Hlp. montenegrinus & + & & \\
\hline Hlp. obscurus & + & + & + \\
\hline
\end{tabular}

used in order to determine the strengths of possible linear associations between the mentioned environmental variables. Canonical correspondence analysis (CCA) was used in order to analyze the relationships between environmental variables and the presence of determined species in sampling sites. The values of the environmental variables were randomly assigned to the individual samples of species composition, and ordination analysis was done with Monte Carlo permutation test with 499 runs. CCA was performed with the CANOCO 4.5 package (Ter Braak, 1986).

\section{Results}

Totally, 1325 individuals belonging to 8 genera and 30 species of Hydrophilidae (21 species) and Helophoridae ( 9 species) were identified from İzmir, Manisa and Aydın

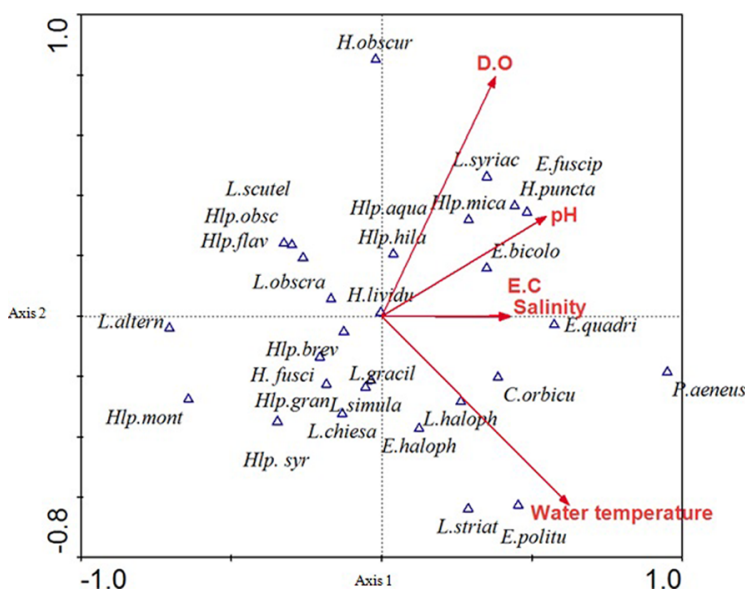

Fig. 2. CCA plot showing species and parameters (L. altern: Laccobius alternus; Hlp. mont: Helophorus montenegrinus; Hlp. brev: Helophorus brevipalpis; H. fusci: Hydrobius fuscipes; Hlp. grand: Helophorus grandis; Hlp. syr: Helophorus syriacus; L. gracil: Laccobius gracilis; L. simula: Laccobius simulatrix; L. chiesa: Laccobius chiesai; L. haloph: Laccobius halophilus; E. haloph: Enochrus halophilus; L. striat: Laccobius striatulus; E. politu: Enochrus politus; C. orbicu: Coelostoma orbiculare; P. aeneus: Paracymus aeneus; E. quadri: Enochrus quadripunctatus; E. bicolo: Enochrus bicolor; H. puncta: Helochares punctatus; E. fuscip: Enochrus fuscipennis; L. syriac: Laccobius syriacus; Hlp. micans: Helophorus micans; Hlp. aqua: Helophorus aquaticus; Hlp. hila: Helophorus hilaris; H. lividu: Helochares lividus; H. obscur: Helochares obscurus; L. scutel: Laccobius scutellaris; Hlp. obsc: Helophorus obscurus; Hlp. flav: Helophorus flavipes; L. obscra: Laccobius obscratus orchymonti).

provinces of Turkey. Table 1 refers to species along with their presence in the study areas.

Water temperature $\left({ }^{\circ} \mathrm{C}\right)$, dissolved oxygen (DO), $\mathrm{pH}$, electrical conductivity (EC), and salinity parameters from several different aquatic bodies were measured and means of provinces were calculated (Tab. 2). The results of the Pearson's correlation analysis shows that there is an intercompatibility between EC and salinity, hence they were positively correlated $(p<0.01)$ (Tab. 3).

CCA was applied in order to identify environmental variables that were associated with the presence of species in the sampled aquatic bodies. Distribution of beetles according to the environmental variables was presented by a CCA plot (Fig. 2). The first two axes accounted for about 55\% of the explained variance (Tab. 4); EC and salinity were found as the primary important parameters in distribution of beetles regarding the whole axis. Dissolved oxygen and $\mathrm{pH}$ parameters positively correlated with the first axis while water temperature was negatively correlated. Distributions of Enochrus quadripunctatus, Coelostoma orbiculare, and Paracymus aeneus were positively related with EC and salinity. Laccobius syriacus, Helophorus micans, Helophorus aquaticus, Helophorus hilaris, Helochares lividus, Helochares punctatus, Helochares obscurus, and Enochrus fuscipennis were positively related with $\mathrm{DO}$ and $\mathrm{pH}$, negatively related with water temperature. Temperature was determined as the most effective factor for Laccobius halophilus, furthermore, Enochrus politus, Laccobius striatulus and Enochrus halophilus were also closely 
A. Akünal and E.G. Aslan: Knowl. Manag. Aquat. Ecosyst. 2017, 418, 43

Table 2. Minimum, maximum, mean values and standard error of physicochemical parameters according to study areas.

\begin{tabular}{llll}
\hline & & Study areas \\
\cline { 2 - 4 } & Aydın & Manisa & \multicolumn{1}{c}{ İzmir } \\
\hline Parameters & Mean \pm SE & Mean \pm SE & Mean \pm SE \\
& Min-Max & Min-Max & $26.23 \pm 1.07$ \\
Water temperature $\left({ }^{\circ} \mathrm{C}\right)$ & $23.316 \pm 0.88$ & $25.203 \pm 0.62$ & $21.3-36.3$ \\
& $31.23-36.2$ & $18.9-32.3$ & $3.266 \pm 0.873$ \\
Dissolved oxygen $(\mathrm{mg} / \mathrm{L})$ & $5.262 \pm 0.675$ & $4.683 \pm 0.863$ & $1.050-18.88$ \\
& $0.66-20.10$ & $1.25-22.17$ & $8599 \pm 5368$ \\
Electrical conductivity $(\mathrm{EC})(\mu \mathrm{S} / \mathrm{cm})$ & $1481 \pm 378$ & $581.8 \pm 76.9$ & $200-79041$ \\
& $11-14098$ & $3.9-2203.0$ & $5.61 \pm 3.69$ \\
Salinity $(\mathrm{ppt})$ & $1.265 \pm 0.390$ & $0.2657 \pm 0.02$ & $0.0-62.03$ \\
& $0.0-13.37$ & $0.0-0.90$ & $8.160 \pm 0.10$ \\
pH & $8.5857 \pm 0.95$ & $8.407 \pm 0.10$ & $7.21-8.93$ \\
& $7.39-10.17$ & $7.19-9.46$ &
\end{tabular}

Table 3. Results of Pearson's correlation analysis for the measured physicochemical parameters.

\begin{tabular}{llll}
\hline & Water temperature $\left({ }^{\circ} \mathrm{C}\right)$ & Dissolved oxygen $(\mathrm{mg} / \mathrm{L})$ & Electrical conductivity $(\mu \mathrm{S} / \mathrm{cm})$ \\
\hline Dissolved oxygen $(\mathrm{mg} / \mathrm{L})$ & 0.221 & & \\
& 0.028 & & \\
Electrical conductivity $(\mu \mathrm{S} / \mathrm{cm})$ & $0.295^{* *}$ & -0.073 & \\
& 0.003 & 0.474 & 0.094 \\
$\mathrm{pH}$ & 0.082 & 0.181 & 0.355 \\
Salinity ppt & 0.418 & 0.074 & $0.965^{* *}$ \\
& 0.316 & -0.087 & 0.000 \\
\hline$* *$ & 0.001 & 0.390 & 0.075 \\
& &
\end{tabular}

Table 4. Summary of CCA analyses.

\begin{tabular}{|c|c|c|c|c|c|}
\hline Axes & 1 & 2 & 3 & 4 & Total inertia \\
\hline Eigenvalues & 0.550 & 0.454 & 0.416 & 0.294 & 9.126 \\
\hline Species-environment correlations & 0.893 & 0.821 & 0.873 & 0.809 & \\
\hline Cumulative percentage variance of species data & 6.0 & 11.0 & 15.6 & 18.8 & \\
\hline Cumulative percentage variance of species-environment relation & 29.9 & 54.6 & 77.2 & 93.1 & \\
\hline
\end{tabular}

related to this parameter. According to the secondary axis; Enochrus quadripunctatus was affected by EC and salinity most, while Laccobius syriacus, Helophorus micans, Helophorus aquaticus, Helophorus hilaris, Helochares lividus, Helochares punctatus, and Enochrus fuscipennis were strongly correlated with dissolved oxygen and $\mathrm{pH}$, and negatively correlated with temperature. In addition, habitat preferences of Laccobius scutellaris, Helophorus obscurus, Helophorus flavipes, Laccobius obscratus, Laccobius alternus, Helophorus montenegrinus, Helophorus brevipalpis, Hydrobius fuscipes, Helophorus grandis, Helophorus syriacus, Laccobius chiesai, Laccobius simulatrix, and Laccobius gracilis were found partially related with high level of oxygen and $\mathrm{pH}$ (Fig. 2).

\section{Discussion}

Water temperature is the most effective environmental variable in development rate in terrestrial and aquatic ectotherms (Ragland and Kingsolver, 2008), and insects are affected from the changes of temperature during their life time especially in such periods as egg stage and embryonic development (Chuche and Thiéry, 2012). In this study, the mean temperature of 99 aquatic sites were about $24.57^{\circ} \mathrm{C}$. Minimum temperature was measured as $12.30^{\circ} \mathrm{C}$ in Aydın province, and maximum temperature was $36.30^{\circ} \mathrm{C}$ in İzmir, but no specimen was sampled in these extreme values. Angus (1992) indicates that species of Helophoridae need about $20^{\circ} \mathrm{C}$ 
water temperature for larval development in the laboratory conditions, so life-history cannot be completed in lower temperatures. Fairchild et al. (2003) stated that higher water temperatures may allow more rapid completion of larval stages. However, during our field surveys Helophorus obscurus specimens were sampled from waters with 14.5$16.6^{\circ} \mathrm{C}$ temperatures, Laccobius scutellaris and Laccobius simulatrix were sampled from $17.7^{\circ} \mathrm{C}$ water in Aydin (İkizdere) province. According to Arribas et al. (2012), Enochrus bicolor and Enochrus falcarius have similar reactions to low temperature averages, but E. falcarius has relatively higher tolerance to high range of temperatures. Enochrus adults and larvae can live in $28-45^{\circ} \mathrm{C}$ waters and other hydrophilids can tolerate waters with temperatures ranging between 28 and $44.5^{\circ} \mathrm{C}$ (Winterbourn, 1968). In the present study, Enochrus specimens were generally sampled from waters with temperatures ranging $21.2-33.3^{\circ} \mathrm{C}$, all over $20^{\circ} \mathrm{C}$. The measured temperature values for the whole species in the study range between 14.5 and $33.3^{\circ} \mathrm{C}$. That is to say, all species have tolerance to different temperatures for habitat preference.

Dissolved oxygen is one of the most important gases of water which limits and organizes life of aquatic organisms. It is very effective for aerobic organisms and the density in the water changes due to water temperature. Aquatic insects are very sensitive to hypoxia and can be defined based on oxygenation of their aquatic habitats. Larva and pupa stages need more oxygen levels, and during these periods hypoxia has a negative influence upon growth (Hoback and Stanley, 2001). In the present study, minimum and maximum dissolved oxygen levels changed between $0.66-22.17 \mathrm{mg} / \mathrm{L}$ in the sampled aquatic sites. Freshwater habitats have a minimum of $5 \mathrm{mg} / \mathrm{L}$ dissolved oxygen for continuation of aquatic life (EPA, 1997). However, Hydrobius fuscipes, Helophorus brevipalpis, H. syriacus, H. obscurus, Enochrus bicolor, E. halophilus, Laccobius chiesai, L. striatulus, L. gracilis, L. halophilus and Paracymus aeneus were sampled from habitats which had oxygen concentrations under $5 \mathrm{mg} / \mathrm{L}$. The above mentioned species usually prefer waters with high temperature and rich nutrients, thus can tolerate low concentrations of dissolved oxygen. Adult hydrophilids and dytiscids have air bubbles under their abdomens for respiration (Winterborn, 1968), which help them live in waters with low limits of oxygen.

$\mathrm{pH}$ is used to indicate the alkalinity or acidity of a substance (EPA, 1997), and effects the whole aquatic organisms and the biochemical activity of these organisms. Safe $\mathrm{pH}$ levels vary from family to family in aquatic insects (Bell, 1971). Aquatic organisms generally live between the range of 5-9 pH waters (Cirik and Cirik, 2005), exceptionally in this study Enochrus bicolor, E. fuscipennis, Helophorus brevipalpis, Laccobius simulatrix, Helochares lividus, $H$. punctatus and Hydrobius fuscipes were sampled in waters above $9 \mathrm{pH}$ level from Aydın and Manisa provinces. Bell (1971) states that when the $\mathrm{pH}$ of the water decreases, the percentage of aquatic insects collaterally decreases. Acidic or alkaline waters which have high hydrogen ions or hydroxyl ions constitute serious problems in gas exchange on the air bubbles of aquatic beetles. The obtained data showed that species of Hydrophilidae and Helophoridae generally prefer waters from alkalinity to neutral, as average $\mathrm{pH}$ of the sampled sites was 8.43 .
Saline inland waters are widespread especially in arid and semi-arid regions of the world and salinity levels of these habitats are adversely affected by human activities, with a corresponding loss of biodiversity. Salinity is affected directly or indirectly by dissolved oxygen, $\mathrm{pH}$, and nutrient factors in aquatic systems (Velasco et al., 2006). Electrical conductivity is comprised of dissolved salts in waters and significantly correlated with salinity (Göksu, 2003). In this study, salinity values were found $<1 \mathrm{ppt}$ in most of the sampling sites. In Aydin province, sampled sites generally consisted of temporary rain water; therefore Helophorus species were mostly sampled from these freshwaters. No specimens were sampled from waters with high salinity levels such as $3.81 ; 3.89 ; 6.34 ; 9.45 ; 13.37$ ppt in Aydın. Same situation was valid for Manisa province and its districts. In İzmir, many aquatic habitats displayed features of freshwater except from the coastal areas which is supported by the composition of the species. But, Enochrus bicolor and Paracymus aeneus specimens were sampled from a coastal wetland of İzmir (Aliaga) of where salinity was measured 62.03 ppt. Species living in high salinity levels are generally endemic or native to those aquatic habitats. According to this, E. bicolor and P. aeneus are likely to be potential indicator species of salinity, generally distributed in saline ecosystems. Similarly, Picazo et al. (2012) stated that Paracymus aeneus, Enochrus bicolor, E. politus and Berosus hispanicus were indicator species of coastal wetlands, and these species had high tolerance to salinity. Changes in salinity affect aquatic biota either directly or indirectly, and only limited species can tolerate high salinity levels or such changes. Among Coleoptera; hydraenids, dytiscids and hydrophilids contain species that live in broad ranges of salinity (Velasco et al., 2006). Therefore, obtained data are in accordance with literature. According to CCA results, main environmental variables which were effective on species distributions are salinity, electrical conductivity and water temperature. Our results are in line with many other studies which are about similar factors responsible of habitat preferences of aquatic insects (Shieh and Yang 2000; Baptista et al., 2001; Céspedes et al., 2013).

In conclusion, species composition of Hydrophilidae and Helophoridae specimens distributed in İzmir, Manisa and Aydın provinces (representing coastal Aegean part of Turkey) are generally influenced by conductivity, salinity and temperature of wetlands. After all, each species prefers different sets of physicochemical parameters. Therefore, species composition of hydrophilids and helophorids as a whole cannot be considered as suitable indicators of water quality. Ecological information regarding habitat preferences provided herein will be a crucial task in future studies in order to understand the presence and distribution of these aquatic beetles in Turkey.

Acknowledgements. The study was supported by Department of Scientific Research Project Management of Süleyman Demirel University with the Project Number SDUBAP (3621-D2-13). We are very grateful to Asst. Prof. Özgür KOSKAN (Süleyman Demirel University, Department of Animal Science) for his helps about statistical analyses. 


\section{References}

Angus RB. 1992. Süsswasserfauna von Mitteleuropa (Insecta: Coleoptera: Hydrophilidae: Helophorinae). Jena: Gustav Fischer Verlag, $144 \mathrm{p}$.

Arimoro FO, Ikomi RB. 2009. Ecological integrity of Upper Warri River, Niger Delta using aquatic insects as bioindicators. Ecol Indic 9: 455-461.

Arribas P, Velasco J, Abellán P, et al. 2012. Dispersal ability rather than ecological tolerance drives differences in range size between lentic and lotic water beetles (Coleoptera: Hydrophilidae). J Biogeogr 39: 984-994.

Baptista DF, Dorvillé LFM, Buss DF, Nessiamian JL. 2001. Spatial and temporal organization of aquatic insect assemblages in the longitudinal gradient of a tropical river. Rev Bras Biol 61: 295-304.

Bell HL. 1971. Effects of low pH on the survival and emergence of aquatic insects. Water Res 5: 313-319.

Céspedes V, Pallarés S, Arribas P, Millán A, Velasco J. 2013. Water beetle tolerance to salinity and anionic composition and its relationship to habitat occupancy. $J$ Insect Physiol 59: 1076-1084.

Chuche J, Thiéry D. 2012. Egg incubation temperature differently affects female and male hatching dynamics and larval fitness in a Leafhopper. Ecol Evol 2: 732-739.

Cirik S, Cirik S. 2005. Limnoloji. İzmir: Ege Üniversitesi Su Ürünleri Fakültesi Yayınları, 135 p.

EPA. 1997. Volunteer stream monitoring: a methods manual. http:// water.epa.gov/type/rsl/monitoring/upload/2002_08_13_volunteer stream stream.pdf.

Ertorun N, Tanatmis M. 2009. Contributions to the Hydrophilidae (Polyphaga: Coleoptera) species diversity of South Marmara Region (Turkey). Biodivers Conserv 2: 7-17.

Fairchild GW, Cruz J, Faulds AM, Short AEZ. 2003. Microhabitat and landscape influences on aquatic beetle assemblages in a cluster of temporary and permanent ponds. J North Am Benthol Soc 2: 224-240.

Göksu ZL. 2003. Su Kirliligi. Adana: Nobel Kitabevi, 232 p.

Guareschi S, Gutiérrez-Cánovas C, Picazo F, et al. 2012. Aquatic macroinvertebrate biodiversity: patterns and surrogates in mountainous Spanish national parks. Aquat Conserv 22: 598-615.

Heino J. 2009. Biodiversity of aquatic insects: spatial gradients and environmental correlates of assemblage-level measures at large scales. Freshw Rev 2: 1-29.

Hoback WW, Stanley DW. 2001. Insects in hypoxia. J Insect Physiol 47: $533-542$.

İncekara Ü, Darılmaz MC, Mart A, Polat A, Karaca H. 2009. Faunistic study on two sister plain (Bafra and Çarsamba) aquatic Coleoptera fauna in Turkey: two similar geography but rather different fauna, with a new record. Mun Ent Zool 4: 25-138.

İncekara Ü, Polat A, Darılmaz MC, Mart A, Tasar GE. 2010. Aquatic Coleoptera fauna of Ramsar Site Sultan Sazlıgı (Kayseri, Turkey) and its surroundings: new distribution records of four species from the southern limit of its range. Arch Biol Sci 62: 1181-1191.

Kiyak S, Canbulat S, Salur A, Darılmaz MC. 2006. Additional notes on aquatic Coleoptera fauna of Turkey with a new record (Helophoridae, Hydrophilidae). Mun Ent Zool 1: 273-278.
Mart A. 2009. Water scavenger beetles (Coleoptera: Hydrophilidae) provinces of Central Black Sea Region of Turkey. J Entomol Res Soc 11: 47-70.

Mart A, İncekara Ü, Karaca H. 2010. Faunistic study of the aquatic beetles (Coleoptera: Helophoridae) in the Bayburt, Giresun, Gümüshane, Ordu and Trabzon provinces of Turkey. Turk J Zool 34: 509-521.

Mart A, Tolan R, Caf F, Koyun M. 2014. A faunistic study on aquatic Coleoptera (Helophoridae: Hydrophilidae) species in Elazig province, Turkey. Pak J Zool 46: 681-696.

Pallarés S, Arribas P, Céspedes V, Millán A, Velasco J. 2012. Lethal and sublethal behavioural responses of saline water beetles to acute heat and osmotic stres. Ecol Entomol 37: 508-520.

Picazo F, Bilton DT, Moreno JL, Sánchez-Fernández D, Millán A. 2012. Water beetle biodiversity in Mediterranean standing waters: assemblage composition, environmental drivers and nestedness patterns. Insect Conserv Divers 5: 146-158.

Polat A, İncekara Ü, Mart A. 2010. A faunistic study on the Helophoridae, Hydrophilidae and Hydrochidae (Coleoptera) in Samsun and Tokat provinces (Turkey). Turk Entomol Derg 34: 227-239.

Ragland GJ, Kingsolver JG. 2008. The effect of fluctuating temperatures on ectotherm life-history traits: comparisons among geographic populations of Wyeomyia smithii. Evol Ecol Res 10: $29-44$.

Ramnik Kour JST, Sharma S. 2011. Studies on the occurrence and seasonal abundance of aquatic Coleoptera in relation to some physicochemical parameters of water of Gharana Wetland Reserve Jammu (J\&K, India). Bioscan 6: 257-261.

Shieh SH, Yang PS. 2000. Community structure and functional organisation of aquatic insects in on agricultural mountain stream of Taiwan: 1985-1986 and 1995-1996. Zool Stud 39: 191-202.

Smith ND, Golladay SW. 2011. Coleoptera indicator species in wet vs. dry climate regimes in three southwestern Georgia wetland types. In: Proceedings of the 2011 Georgia Water Resources Conference, April 11-13, 2011, University of Georgia.

Tasar GE, Polat A, Darılmaz MC, et al. 2012. A good sample to concurrent fauna: study on aquatic Coleoptera fauna (Adephaga and Polyphaga) of Lake Van Basin (Turkey), with some zoogeographic remarks. J Entomol Res Soc 14: 27-37.

Ter Braak CJF. 1986. Canonical correspondence analysis: a new eigenvector technique for multivariate direct gradient analysis. Ecology 67: 1167-1179.

Topkara ET, Balık S. 2010. Contribution to the knowledge on distribution of the aquatic beetles (Ordo: Coleoptera) in the Western Black Sea Region and its environs of Turkey. Turk J Fish Aquat Sci 10: 323-332.

Velasco J, Millán A, Hernandez J, et al. 2006. Response of biotic communities to salinity changes in a Mediterranean hypersaline stream. Saline Syst 2: 12

Wahizatul AA, Long SH, Ahmad A. 2011. Composition and distribution of aquatic insect communities in relation to water quality in two freshwater streams of Hulu Terengganu, Terengganu. JSSM 6: 148-155.

Winterborn MJ. 1968. The faunas of thermal water in New Zealand. Tuatara 16: 111-121.

Cite this article as: Akünal A, Aslan EG. 2017. Ecological investigations on Hydrophilidae and Helophoridae (Coleoptera) specimens gathered from several water bodies of Western Turkey. Knowl. Manag. Aquat. Ecosyst., 418, 43. 